\title{
SOIL ECOLOGICAL SAFETY EVALUATION FOR BIVALENT TRANSGENIC COTTON PLANTS: ROOT EXUDATES VERSUS SOIL ENZYME ACTIVITIES AND SOIL MICROBIAL DIVERSITY
}

\author{
WU, H-S. ${ }^{* 1}-$ SHI, X. ${ }^{1}-$ LI, J. ${ }^{1}-$ LIU, Y-D. ${ }^{2}-$ XU, Y. ${ }^{1}-$ CHEN, S-Y. ${ }^{1}-$ REN, Q-Q. ${ }^{1}-$ XIAO, S-H. ${ }^{* 3}$ \\ ${ }^{I}$ Department of Agricultural Resources and Environment, Nanjing University of Information \\ Science and Technology, Nanjing 210044, China \\ ${ }^{2}$ Yangzhou Polytecnic Institute, Yangzhou 225127, China
}

${ }^{3}$ Institute of Industrial Crops, Jiangsu Academy of Agricultural Sciences, Nanjing 210094, China

*Corresponding authors

e-mail:wuhsglobe@sina.com,wuhsluck@163.com; phone: +86-25-5869-9871

(Dr. Professor Hong-sheng Wu)

e-mail:njxsh@sina.com; phone: +86-25-84390363

(Professor Song-hua Xiao)

(Received $7^{\text {th }}$ Jul 2015; accepted $16^{\text {th }}$ Jan 2016)

\begin{abstract}
Pot experiments were conducted to assess the possibly adverse effect of transgenic Bt- and CpTI-cotton (Bacillus thuringiensis and cowpea trypsin inhibitor cotton) on soil ecosystem. Soil enzymes activities and microbial molecular community and diversity based on 16s- and 18s-PCR-DGGE (polymerase chain reaction-denaturing gradient gel electrophoresis) profiles were determined by adding root exudates of Bt- and CpTI-cotton into soil. Results showed that the root exudates of transgenic cotton seedlings increased the soil catalase activity by $21.8 \%$ to $32.7 \%$. The soil urease activity was decreased by $11.0 \%$ while the activity in the treatment of $1 \mathrm{ml} / 350 \mathrm{~g}$ soil was increased by $18.1 \%$ compared to control. The invertase activity in the treatment of $1 \mathrm{ml} / 350 \mathrm{~g}$ soil was increased by $54.2 \%$, however, the activity in the treatments of 2 and $4 \mathrm{ml} / 350 \mathrm{~g}$ soil was decreased by from $25 \%$ to $29.2 \%$. The total 16 sPCR-DGGE lane bands of bacterial community and diversity were almost not different. However, the effect pattern of root exudates of transgenic cotton on soil fungal community and diversity was differed from bacteria. The fungal community number and composition were changed. Though some dominant community disappeared and other newly dominant community appeared, the fungal stability index was increased. Results suggested there was little significantly adverse effect of Bt- and CpTI-cotton on soil ecosystem.

Keywords: transgenic Bt+CpTI cotton, root exudates, soil enzymes, soil microbial diversity, biosafety assessment
\end{abstract}

Abbreviations: Trangenic $\mathrm{Bt}+\mathrm{CpTI}$ cotton-transgenic Bacillus thuringiensis + cowpea trypsin inhibitor cotton; CAT-catalase

\section{Introduction}

Genomic technologies have been used to improve cultivated crop species, which provides an opportunity to transfer new specific traits of interest into other valuable genotypes (GMO-genetically modified organism) within a short period of time, and greatly reduces costs by promoting crop yield and environmental risk by decreasing the use of chemical insecticides (Peferoen, 1997; Baute et al., 2002; Bourguet et al., 2002; Rahman et al., 2015). On a global basis in 2010, about 15.4 million farmers grew biotech crops on about 1 billion ha (James, 2010). 
Cotton (Gossypium hirsutum L.) is one of the most economically important crops in the world. The first commercially available transgenic cotton expressing an insecticidal protein (Cry1Ac from Bt) was produced in the United Sates in 1995 (Environmental Protection Agency, 1998). Subsequently the growing area of Bt cotton cultivars has steadily increased, especially in China and India (Wu et al., 2011; Raman et al., 2015; Zaman et al., 2015). Proteinase inhibitor (PI) gene-transformed cotton plants, especially the CpTI gene (cowpea trypsin inhibitor gene) found and derived from edible parts of cowpea, were also introduced for broader insect-resistance. Bt and CpTI, together or individually, defend transgenic cotton from attack and damage by specific pest insects.

As a novel technology, however, there have beenargues about the safety of transgenic crops that still continue today. Since the original production of transgenic plants, there has been worldwide debate about the safe use of these plants and their products. The potential risks and benefits of transgenic plants should be evaluated independently and objectively. Risk assessment of transgenic crops is a basic prerequisite for monitoring the possible risks that could arise upon the release and use of transgenic plants (Talas-Ogras, 2011). Recently regulations have been developed to address the risks of releasing transgenic plants into the natural environment. Clearly, future agricultural ecosystems, and ultimately also natural ecosystems, will be challenged by the large-scale introduction of transgenic plants, containing entirely novel genes and gene products in new combinations at high frequencies. All of these may have unknown impacts on their associated complex of non-target organisms, i.e. all organisms that are not targeted by the insecticidal proteins produced by the transgenic plants (Velkov et al., 2005).

Such effects have been investigated numerous times. Growing $\mathrm{Bt}$ rice cultivars effectively decreased in situ $\mathrm{CH}_{4}$ emission fluxes and methanogenic archaeal and methanotrophic bacterial community abundance and diversity (Han et al., 2013). However, increasing the fructose content of transgenic cotton (Bt and chi) (Modirroosta et al., 2014) had no direct adverse impacts on honeybees feeding on transgenic cotton pollen (Liu et al., 2005a, 2005b). No Bt protein was found to be taken up from soil by non-Bt corn, carrot, radish, or turnip grown in soil in which Bt corn had been grown or into which biomass of Bt corn had been incorporated (Stotzky, 2004; Rahman et al., 2015; Zaman et al., 2015).No significant direct adverse effects of transgenic cotton pollen $(\mathrm{Bt}+\mathrm{CpTI})$ on the pollinating beetle Haptoncus luteolus (Chen et al., 2011) and on organisms (earthworms, nematodes, protozoa, bacteria, fungi) in soil or in vitro were found(Rahman et al., 2015; Zaman et al., 2015).

Interestingly, larvicidal proteins encoded by cry genes from $B$. thuringiensis are released in root exudates from transgenic $B$. thuringiensis corn, rice, and potato but not from B. thuringiensis canola, cotton, and tobacco (Saxena et al., 2004; Rahman et al, 2015). The observed pattern of arbuscular mycorrhizal fungal colonization of $\mathrm{Bt}$ transgenic cotton was virtually identical among both conventional and GM cultivars of cotton at each assessment, clearly indicating that colonization by AM fungi was not affected by the expressed transgenic traits (Knox et al., 2008). Morphologically, there are significant reductions in transgenic cotton plant height making them favorable for breeding. Yield was significantly increased for transgenic lines. Fiber quality of transgenic lines was not affected when compared with non transgenic lines but needs further studies to understand the complex molecular mechanisms for resistance management and biosafety studies to develop new Bt cotton varieties (Rashid et al., 2009; Rahman et al., 2015). Transgenic insect-resistant cotton expressing the Cry1Ac and/or CpTI protein has caused significant seasonal variation in the number of bacteria, fungi, 
azotobacter, denitrifying bacteria, and ammonia-oxidizing bacteria and in diversity indices of microorganisms, but no significant differences in microbial population sizes or diversity indices attributable to long-term cultivation of transgenic cotton ( $\mathrm{Li}$ et al., 2011). Using transgenic plants expressing Cry1Ie might delay the development of Bt-resistant insects in the field while the former genes-transformed into cotton convey insect resistance to transgenic cotton (Zhang et al., 2013). Cultivating Cry $3 B b$ protein Bt maize is unlikely to adversely affect soil ecology in the short term but it is still unknown in the long term cultivation (Devare et al., 2007).

No negative effect of different $\mathrm{Bt}$ rice varieties on the fitness of Folsomia candida through either diet or soil exposure in a laboratory test was obtained (Yuan et al., 2013). Transgenic cotton did not cause changes in populations of acarids and did not substantially reduce numbers of predators; its effects on aphids were inconsistent (Men et al., 2004). Molecular analysis of the bacterial community also showed no significant impact on the dominant members of the bacterial community and soil protease activity was not inhibited by the release of constitutively over-expressed protease inhibitor (Riglietti et al., 2008). No significant harmfu impact on CFUs of bacteria, actinomycetes and fungus between the Bt and non-Bt cotton rhizosphere during cropping season at one particular stage(Zwahlen et al., 2007; Zaman et al., 2015), even at far higher concentration of the Bt proteins (Rahman et al., 2015), no recombination event was detected between plant DNA and soil bacteria (Velasco et al., 2013), but other factors may be involved (Rui et al., 2005) and more studies are needed to assess the impact of the continuous release of $C r y l A b$ via root exudates and plant biomass on the soil ecosystem (Zwahlen et al., 2007).

Crop residues are the primary source of carbon in soil, and root exudates govern which organisms reside in the rhizosphere. Any change to the quality of crop residues and rhizosphere inputs could modify the dynamics of the composition and activity of organisms in soil. Insect-resistant Bt crops have the potential to change the microbial dynamics, biodiversity, and essential ecosystem functions in soil, because they usually produce insecticidal Cry proteins through all parts of the plant(Rahman et al., 2015; Zaman et al., 2015). It is crucial that risk assessment studies on the commercial use of Bt crops consider the impacts on organisms in soil. Generally, few or no toxic effects of Cry proteins on woodlice, collembolans, mites, earthworms, nematodes, protozoa, and the activity of various enzymes in soil have been addressed (Icoz and Stotzky, 2008; Rahman et al., 2015). Although some effects, ranging from no effect to minor and significant effects, of Bt plants on microbial communities in soil have been reported, they were mostly the result of differences in geography, temperature, plant variety, and soil type and, in general, were transient and not related to the presence of the Cry proteins (Icoz and Stotzky, 2008).

Considerable research has now been conducted on the effects of transgenic plants on soil microorganisms. Most studies to date suggest that Bt plants that have been released cause minor changes in microbial community structures that are often transient in duration. However, impacts of two-gene transgenic cotton (Bt- and CPTI- gene) on soil microbial community structure and functionhave received little attention.

Ecological stress or other environmental changes in soil ecosystem can be judged in advance through some sensitive/warning indicators, including biological and biochemical properties of the soil, e.g. microbial activity and the activities of soil enzymes (Nannipieri et al., 2003; Gomez et al., 2006). It is likely that those sensitive soil parameters may be affected by cultivation of Bt-CPTI-cotton. So, the objective of this study was to examine and assess the effect of Bt- and CpTI-cotton on microbial and 
biochemical indicators in soil of Bt+CpTI-cotton crops in a subtropical agro-ecosystem. The purpose of this study was to check unknown and possible changes due to the presence of root exudates of transgenic insect-resistant cotton, especially the responses of soil key enzyme activities and soil microbial community based on PCR-DGGE.

\section{Materials and Methods}

\section{Transgenic and conventional cotton seed}

Cotton seeds of bivalent (against $\mathrm{Bt}+\mathrm{CpTI}$ ) transgenic cotton, bred by Research Institute of Cotton, Chinese Academy of Agricultural Sciences, obtained from Jiangsu Academy of Agricultural Sciences, was used as transgenic cotton and cultivar Xinluhan 33, obtained from Jiangsu Academy of Agricultural Sciences, was used as the conventional cotton line. The genes Bt (CrylA) and CpTI (Cowpea Trypsin Inhibitor), effective against cotton bollworm (Helicoverpa armigera Hubner), were contained in the transgenic cotton in the current study.

\section{Collecting root exudates of transgenic cotton seedlings}

The transgenic cotton and conventional parental cotton seeds were dipped in water for $48 \mathrm{~h}$ and surface disinfected with $10 \% \mathrm{H}_{2} \mathrm{O}_{2}$ for 20 minutes. Clean and rinse the seeds. The disinfected cotton seed was germinated in the incubator with $70-90 \%$ humidity and $25^{\circ} \mathrm{C}$. The seedlings with two leaves were transplanted into the soil in pot until the seedlings were grown up to the 5-6 leaf stage then the seedlings were dipped into $2000 \mathrm{ml}$ of distilled water in a beaker for collection of root exudates. The root exudates were collected between 10:00 to 14:00 every day for 14 days. The distilled water containing root exudates of transgenic cotton seedlings were evaporated in a $45^{\circ} \mathrm{C}$ water bath until the liquid was concentrated to $2 \mathrm{ml}$ (concentrated 1000 times) and subsequently stored at $4{ }^{\circ} \mathrm{C}$ for further study.

\section{Experimental design}

The effect of transgenic cotton on soil enzyme activities and soil microbial diversity was assessed in a lab study. As control, the conventional parental cotton root exudates were also simultaneously assessed. Four treatments and three replicates were used in this single factor experiment. The concentrated root exudates (condensed 1000 times) of transgenic or conventional parental cotton xinluhan33 cotton seedlings were added into distilled water at four concentrations: $0(\mathrm{CK}), 1,2,4 \mathrm{ml}$ (T1,T2,T3)of concentrated root exudates (transgenic cotton and non-transgenic cotton respectively) into $100 \mathrm{ml}$ of distilled water. Each mixture of $100 \mathrm{ml}$ of water and root exudates was blended into $350 \mathrm{~g}$ of soil and mixed thoroughly and then this wet soil mixure was placed into a pot (14 $\mathrm{cm} \mathrm{x}$ $8 \mathrm{~cm}$ ). The pots were randomly distributed in a growth chamber with $10 \mathrm{~h}$ of illumination, $25^{\circ} \mathrm{C}$ at daytime and $18{ }^{\circ} \mathrm{C}$ at night time. After 10 days, sampling soil was analyzed for soil enzyme activities and microbial community and diversity.

\section{Determination of catalase, phosphatase, urease and invertase activities in soil treated with root exudates}

Antioxidant enzyme activity (CAT), redox related enzyme activities (phosphatase, urease) and hydrolic enzyme activity (invertase, sucrase, sugar conversion) in the soil 
were measured. All these enzymes were convinced to be associated with the functionality, productivity and buffer capacity in another new pot soil treated with the concentrated root exudates of transgenic and non-transgenic cotton.

\section{Soil catalase activity assay}

The activity of hydrogen peroxidase oxidoreductase (catalase) (EC 1.11.1.6) in soil was determined by back-titrating residual $\mathrm{H}_{2} \mathrm{O}_{2}$ with $\mathrm{KMnO}_{4}$ (Johnson and Temple, 1964) with some modifications.

Place $2 \mathrm{~g}$ wind-dried soil into $100-\mathrm{ml}$ beakers and add 40ml distilled water and $5 \mathrm{ml}$ $0.3 \% \mathrm{H}_{2} \mathrm{O}_{2}$. Incubate the soil samples in the dark at $25^{\circ} \mathrm{C}$ for $20 \mathrm{~min}$ at the back-forth vibrating incubator. Add $5 \mathrm{ml} 6 \mathrm{~mol} \mathrm{~L} \mathrm{~L}^{-1}$ sulfuric acid to stabilize the unbroken $\mathrm{H}_{2} \mathrm{O}_{2}$. Filter the suspension with slow-filter paper. Take $25 \mathrm{ml}$ filtrate solution and titrate it with $0.3 \mathrm{~mol} \mathrm{~L}^{-1} \mathrm{KMnO}_{4}$ till light pink (record volume of $\mathrm{KMnO}_{4}$ used as $\mathrm{B}$ ). Meantime, titrate $25 \mathrm{ml} 0.3 \% \mathrm{H}_{2} \mathrm{O}_{2}$ with $0.3 \mathrm{~mol} \mathrm{~L}^{-1} \mathrm{KMnO}_{4}$ till light pink (record volume of $\mathrm{KMnO}_{4}$ used as A). Here, (A-B) $\times$ actual concentration of $\mathrm{KMnO}_{4}$ was the soil catalase activity. Soil catalase activity was calculated as milliliter of $0.3 \mathrm{~mol} \mathrm{~L}^{-1} \mathrm{KMnO}_{4}$ per gram of soil after $20 \mathrm{~min}$.

\section{Invertase activity assay}

The invertase activity (substrate, $5 \%$ sucrose) ,also sucrase (EC 3.2.1.26), was measured by reducing sugars release in the incubation period of $24 \mathrm{~h}$ at $37^{\circ} \mathrm{C}$ and colorimetrically (Frankenberger and Johanson, 1983) with some midifications.

Put $5 \mathrm{~g}$ wind-dried soil samples into $50 \mathrm{ml}$ conic flask and add $15 \mathrm{ml} 18 \%$ sugar solution, $5 \mathrm{ml} \mathrm{pH} 5.5$ phosphate buffer and 5 drops of toluene. Shake and mix the system. Place the mixture system into the incubator and incubate at $37^{\circ} \mathrm{C}$ for $24 \mathrm{~h}$. Filter the reaction system. Take $1 \mathrm{ml}$ filtrate and place into $50 \mathrm{ml}$ volumetric flask. Add $3 \mathrm{ml}$ 3,5-dinitro salicylic acid. Heat the mixture for $5 \mathrm{~min}$ at the boiling water bath. Subsequently, move the mixture to running water to cold for $3 \mathrm{~min}$. Add distilled water to dilute the yellowish mixture till $50 \mathrm{ml}$. Take $3 \mathrm{ml}$ yellow solution to detect the colormetry at $508 \mathrm{~nm}$ wavelength. The sucrase activity was milligram of glucose produced from sucrose hydrolyzed by invertase after $24 \mathrm{~h}$ per gram soil.ủ

\section{Soil urease assay}

Soil urea amidohydrolase (urease) (EC 3.5.1.5), (substrate, 10\% urea) were determined colorimetrically by the liberated $\mathrm{NH}_{4}{ }^{+}$after $24 \mathrm{~h}$ of incubation at $30{ }^{\circ} \mathrm{C}$ (Kandeler and Gerber, 1988) with modifications.

Place $5 \mathrm{~g}$ of wind-dried passed through $1 \mathrm{~mm}$ into $100 \mathrm{ml}$ conic flask. Add $1 \mathrm{ml}$ toluene into the flask and put it $15 \mathrm{~min}$. Add $10 \mathrm{ml} 10 \%$ urea solution and $20 \mathrm{ml}$ citrate buffer $(\mathrm{pH}$ 6.7) and mix carefully, and the contents were allowed to stand for approximately 15 minutes until the toluene had completely penetrated the soil. A control, in which $10 \mathrm{ml}$ distilled water was substituted for the urea, was run simultaneously for each soil sample. Incubate the mixture at $37^{\circ} \mathrm{C}$ for $24 \mathrm{~h}$. Dilute the mixture with $38^{\circ} \mathrm{C}$ hot water till $100 \mathrm{ml}$ and shake carefully and filter the mixture into the conic flask. Take $3 \mathrm{ml}$ filtrate and put it into $50 \mathrm{ml}$ volumetric flask. Add 10ml distilled water and shake thoroughly. Add $4 \mathrm{ml}$ sodium phenol and mix carefully, then add $3 \mathrm{ml}$ sodium hypochlorite and shake thoroughly, put it $20 \mathrm{~min}$. Dilute to $50 \mathrm{ml}$ with distilled water. The blue mixture was 
determined at $578 \mathrm{~nm}$ wavelength within $1 \mathrm{~h}$ colormetrically. The soil urease activity was expressed as $\mathrm{NH}_{3}-\mathrm{N}$ milligram per gram soil after $24 \mathrm{~h}$.

\section{Phosphatase activity assay}

Acid phosphomonoesterase (phosphatase) (EC 3.1.3.2) was determined colorimetrically by the liberated phenolphthalein after the substrate $1 \%$ sodium phenolphthalein phosphate, was incubated $1 \mathrm{~h}$ at $30^{\circ} \mathrm{C}$ following the modified method by Serrasolsas and Khanna (1995) with modifications.

Place $5 \mathrm{~g}$ wind-dried soil samples into $50 \mathrm{ml}$ volumetric flask and add $1 \mathrm{ml}$ toluene. Plug the mouth of the flask and shake gently for $15 \mathrm{~min}$. Add $5 \mathrm{ml}$ disodium phenol phosphate $(6.75 \mathrm{~g}$ disoudium phenol phosphate dissolved in $1000 \mathrm{ml}$ distilled water) and $5 \mathrm{ml}$ responding buffer ( $\mathrm{pH} 5.0$ acetate buffer for acidic phosphatase, $\mathrm{pH} 7.0$ citrate buffer for nutral phosphatase, and $\mathrm{pH} 10.0$ borate buffer for alkali phosphatase), disodium phenolphosphate replaced by $5 \mathrm{ml}$ distilled water was used as control for each soil sample. Shake and mix carefully. Place into the incubator. Incubate at $37{ }^{\circ} \mathrm{C}$ for $24 \mathrm{~h}$.

Dilute the mixture inside the flask with $38{ }^{\circ} \mathrm{C}$ hot water till $50 \mathrm{ml}$ (toluene floating up the scale-line) and filter. Take $1 \mathrm{ml}$ filtrate and add into $100 \mathrm{ml}$ volumetric flask. Add 5 $\mathrm{ml} \mathrm{pH} 9.0$ borate buffer and $3 \mathrm{ml} 2.5 \%$ potassium ferricyanide and $3 \mathrm{ml} 0.5 \%$ 4-Aminoantipyrine. Shake and mix carefully. Add distilled water to volume. Optical density of the stable pink liquid after $30 \mathrm{~min}$ was measured at $570 \mathrm{~nm}$. The phosphatase activity was calculated as phenol milligram per gram soil.

\section{Extraction and purification of pot soil total DNA and DNA amplification with PCR}

Each soil sample was homogenized before the total DNA was extracted from $1.0 \mathrm{~g}$ of the sample using a PowerSoil ${ }^{\circledR}$ DNA Isolation Kit based on the instruction manual provided by the manufacturer (MO BIO Laboratories, Inc., Carlsbad, CA, USA). The DNA fragments were amplified with 16sDNA using GC-clamp primers (338F-GC: 5'-CGCCCGCCGCGCGCGGCGGGCGGGGCGGGGGCACGGGGGGCCTACGGG AGGCAGCAG-3', 518R: ATT ACC GCG GCT GG) for soil bacterium (Muyzer et al., 1993) and NS1-GC fung primers (White et al., 1990; May et al., 2001; Luo et al., 2009) for soil fungus (NS1: 5'-GTAGTCATATGCTTGTCTC-3', GC-fung: 5'-GC clamp-ATTCCCCGTTACCCGTTG-3' with GC clamps 5'-CGCCCGCCGCGCCCCGCGCCCGGCCCGCCGCCC CCGCCCC-3'). PCR amplification of a 16S rRNA gene fragment was performed with the primers $338 \mathrm{~F}+\mathrm{GC}$ and 518R to amplify the V3-V6 region. PCR amplification of an 18S rRNA gene fragment was performed with the primers GC -fung and NS1 to amplify the IST3 region. All bacterial and fungal PCRs were conducted in $25-\mu 1$ and $50-\mu 1$ volumes, respectively. The total soil genomic DNA extracted and purified was eluted with $100 \mu$ of the DNA elution solution included in the kit.

The bacterial PCR system was composed of $1.0 \mu \mathrm{l}$ of DNA template, $2 \mu \mathrm{l}$ of forward primer, $2 \mu \mathrm{l}$ of reverse primer, $12 \mu \mathrm{l}$ of $2 \times \mathrm{PCR} \operatorname{mix}$ (TaKaRa Taq polymerase $1.25 \mathrm{U} / 25$ $\mu$, TaKaRa, Dalian, China, dNTP Mixture $2 \times$ conc., 0.4 mM each, Taq Buffer $2 \times$ conc., 3 $\mathrm{mM} \mathrm{Mg}{ }^{2+}$, dye Marker Tartrazine/Xylene Cyanol FF), and $10 \mu 1$ of double-distilled water in a final volume of $25 \mu$. The bacterial PCR was conducted in a TP professional Standard Thermocycler (Biometra, Germany) and consisted of an initial denaturation at $94{ }^{\circ} \mathrm{C}$ for $5 \mathrm{~min}, 35$ cycles of denaturation at $94{ }^{\circ} \mathrm{C}$ for $45 \mathrm{~s}$, annealing at $55^{\circ} \mathrm{C}$ for $45 \mathrm{~s}$, and extension at $72{ }^{\circ} \mathrm{C}$ for $60 \mathrm{~s}$, and a final extension at $72{ }^{\circ} \mathrm{C}$ for $10 \mathrm{~min}$. 
The fungal PCR system was composed of $2.0 \mu \mathrm{l}$ of DNA template, $2 \mu 1$ of forward primer, $2 \mu \mathrm{l}$ of reverse primer, $25 \mu \mathrm{l}$ of $2 \times$ PCR mix (TaKaRa Taq polymerase $1.25 \mathrm{U} / 25$ $\mu 1$, TaKaRa, Dalian, China, dNTP Mixture $2 \times$ conc., $0.4 \mathrm{mM}$ each, Taq Buffer $2 \times$ conc., 3 $\mathrm{mM} \mathrm{Mg}^{2+}$, dye Marker Tartrazine/Xylene Cyanol FF) and $19 \mu \mathrm{l}$ of double-distilled water in a final volume of $50 \mu \mathrm{l}$. The fungal PCR was conducted in a TP professional Standard Thermocycler (Biometra, Germany) and consisted of an initial denaturation at $94{ }^{\circ} \mathrm{C}$ for 4 min, 36 cycles of denaturation at $94^{\circ} \mathrm{C}$ for $60 \mathrm{~s}$, annealing at $55^{\circ} \mathrm{C}$ for $45 \mathrm{~s}$, an extension at $72{ }^{\circ} \mathrm{C}$ for $45 \mathrm{~s}$, and a final extension at $72{ }^{\circ} \mathrm{C}$ for $10 \mathrm{~min}$.

\section{DGGE profiling and microbial community and diversity analysis of soil DNA}

DGGE analysis was performed using the Dcode Universal Mutation Detection System (BioRad Laboratories, Hercules, CA, USA) according to the instruction manual provided by the manufacturer (Quantity One software). Twenty-five milliliters of the PCR products obtained from the bacterial DNA and $50 \mathrm{ml}$ of the PCR products obtained from the fungal DNA were loaded in each well, and electrophoresis was run at $60{ }^{\circ} \mathrm{C}$ for $10 \mathrm{~min}$ at $200 \mathrm{~V}$ and for $16 \mathrm{~h}$ at $80 \mathrm{~V}$ in an $8 \%$ acrylamide/bis-acrylamide $(37.5: 1)$ gel with a 40-60 \% denaturant gradient for bacterial DNA and 25-40 \% for fungal DNA, where 100 $\%$ denaturant contained $7 \mathrm{M}$ urea and $40 \%$ (v/v) formamide (deionized). The gels were silver stained (Radojkovic and Kusic, 2000) and were digitized and analyzed using the Quantity One 4.0 gel analysis software (BioRad). Because each migration position typically corresponds to a different sequence variant, each matrix obtained was considered a taxa presence-absence matrix for statistical analyses. The bands were numbered in order of appearance from the top to the bottom of the gels.

\section{Statistical analysis of data}

The data are presented as the means $( \pm \mathrm{SE})$ from three replicates for each treatment. One-way analysis of variance (ANOVA) was performed using the SPSS Base Ver.11.5 statistical software (SPSS, IL, Chicago, USA). Least significant difference tests were used to test for significant differences in soil enzyme activities (soil CAT, urease, invertase and phospatase) exposed to different root exudates concentrations of transgenic cotton. The significance levels for all analyses were set at $p<0.05$.

The Shannon diversity index for microbial communities was calculated using the following equation: $H^{\prime}=-\Sigma P_{i} \ln P_{i}$, where $P_{i}$ is the relative abundance for the $i^{\text {th }}$ band in the DGGE profiles. The Evenness index for microbial communities was calculated as $\mathrm{E}=\mathrm{H}^{\prime} / \mathrm{lnR}$, where $\mathrm{R}$ (richness) represents the total bands in the DGGE profiles. The Stability index for microbial communities was calculated by $\mathrm{S}=\Sigma\left(\mathrm{Pi} / \mathrm{P}_{\mathrm{i}} \mathrm{max}\right) / \mathrm{n}$, where $\mathrm{P}_{\mathrm{i}}$ max is the maximal abundance in the $\mathrm{i}^{\text {th }}$ band in the DGGE profiles and $\mathrm{n}$ is the number of samples in the DGGE profiles.

\section{Results}

\section{Effect of root exudates of transgenic cotton seedlings on soil catalase activity}

The root exudates of transgenic or non-transgenic cotton seedlings increased the soil CAT activity first and decreased the acitivity of soil CAT when peaking at $2 \mathrm{ml} / 350 \mathrm{~g}$ soil. Compared with control $\left(1.25 \mathrm{KMnO}_{4} \mathrm{ml} \mathrm{g}^{-1}\right.$ soil $)$, the soil CAT activity treated with root exudates of transgenic cotton seedlings increased by $21.8 \%$ to $32.7 \%$, but there was no significant difference between transgenic and non-trangenic cotton (Fig. 1). 


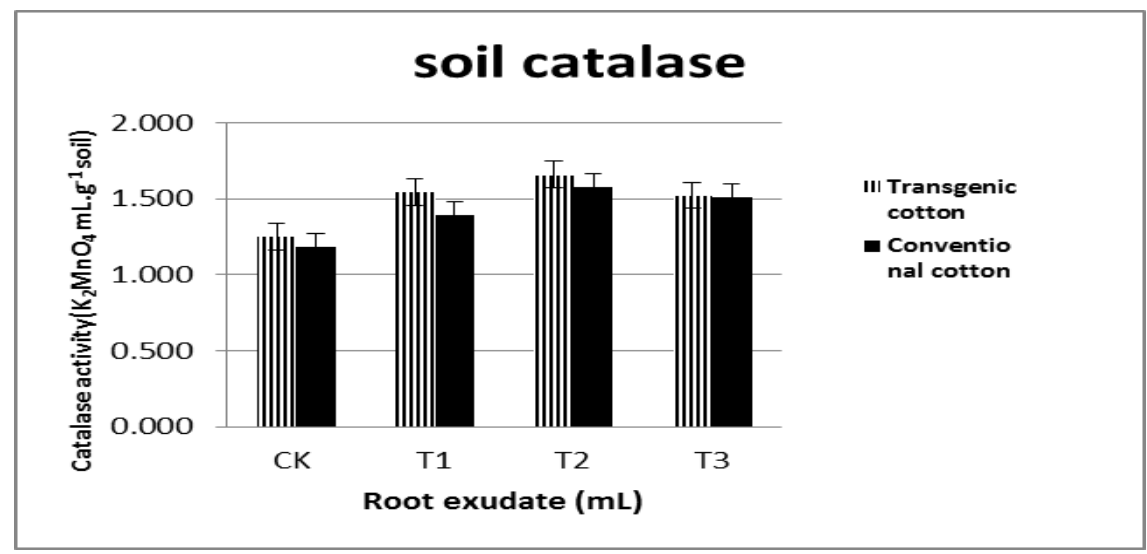

Figure 1. Effect of root exudates from transgenic and nont-transgenic cotton seedlings (Xinluhan-33, containing Bt and CpTI genes) on the soil catalase(CAT) activity. The letters $C K$, $T 1, T 2$, and T3indicated the volume of the concentrated transgenic or non-transgenic cotton root exudates added into the pot soil. Bars are means + SE. Means with the same letters were not significantly different in LSD tests ( $p<0.05)$.

\section{Effect of root exudates of transgenic cotton seedlings on soil urease activity}

The soil urease activity treated with root exudates of transgenic and non-transgenic cotton seedlings was firstly higher than control but then slightly higher and finally less than the control at the highest concentration (Fig. 2). In the highest concentration $(4 \mathrm{ml} / 350 \mathrm{~g}$ soil), the soil urease activity treated with transgenic cotton was decreased by $11.0 \%$ while the activity in the treatment of $1 \mathrm{ml} / 350 \mathrm{~g}$ soil was increased by $18.1 \%$ compared to control. No significant difference between transgenic and conventional cotton.

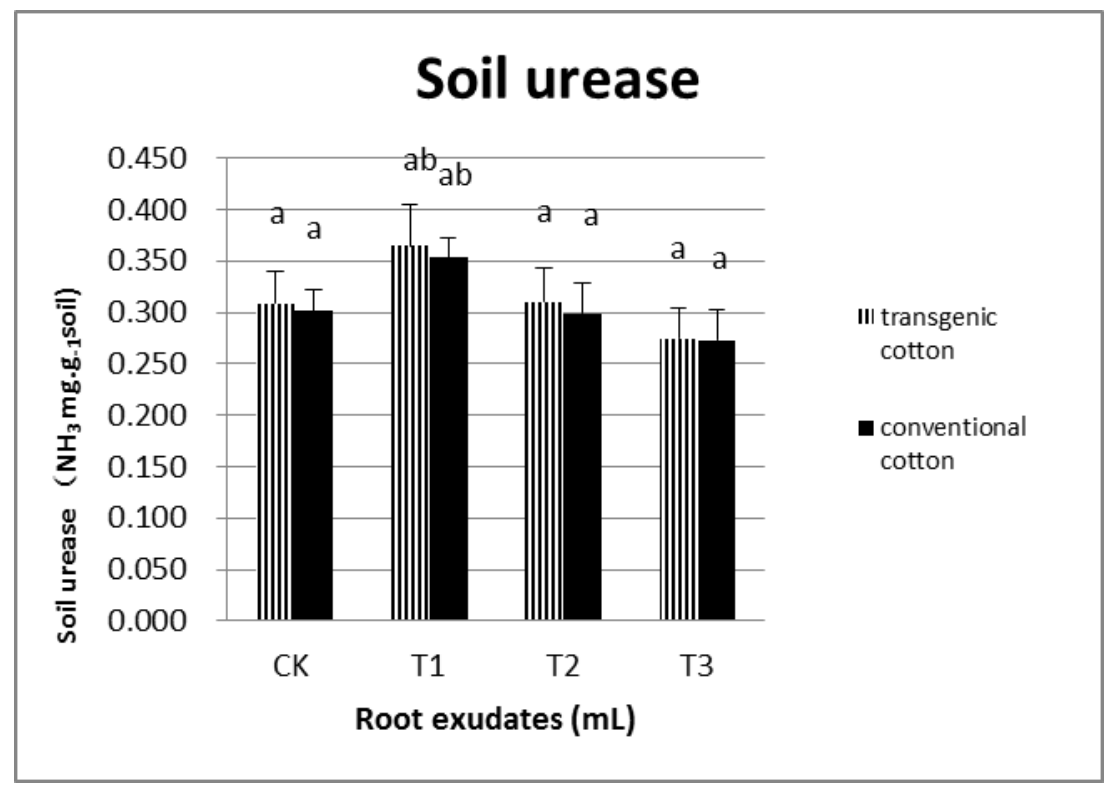

Figure 2. Effect of root exudates from transgenic and nont-transgenic cotton seedlings (Xinluhan-33, containing Bt and CPTI genes) on the soil urease activities. The letters CK, $T 1, T 2$, and T3indicated the volume of the concentrated transgenic or non-transgenic cotton root exudates added into the pot soil. Values are means $\pm S E$. Means with the same letters were not significantly different in LSD tests ( $p<0.05)$. 


\section{Effect of root exudates of transgenic cotton seedlings on soil invertase activity}

Root exudates of transgenic or conventional cotton seedlings could significantly affect the invertase activity of soil. Except the soil invertase activity treated with $1 \mathrm{ml} / 350 \mathrm{~g}$ soil was abruptly ascended, the activity in the other treatments was all sharply descended (Fig. 3). The invertase activity in the treatment of $1 \mathrm{ml} / 350 \mathrm{~g}$ soil was increased by 54.2 $\%$, however, the activity in the treatments of 2 and $4 \mathrm{ml} / 350 \mathrm{~g}$ soil was decreased by from $25 \%$ to $29.2 \%$ relative to control. No significant difference was found between treatment of transgenic and non-transgenic cotton.

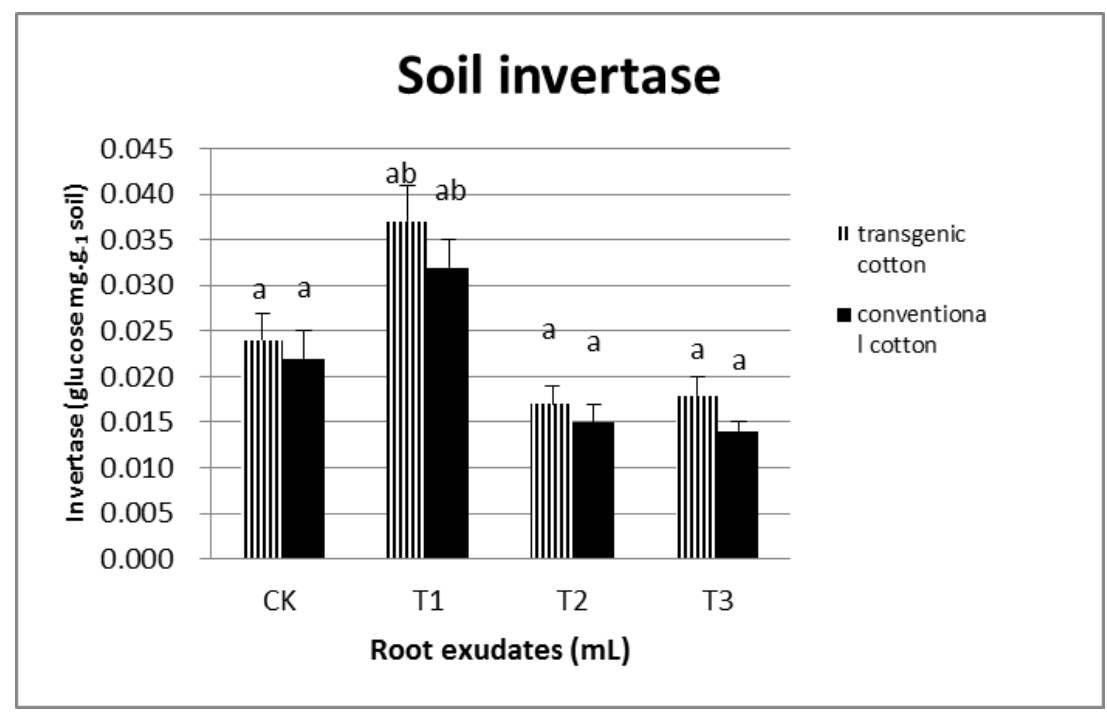

Figure 3. Effect of root exudates from transgenic and nont-transgenic cotton seedlings (Xinluhan-33, containing Bt and CpTI genes) on the soil invertase activity. The letters

$C K, T 1, T 2$, and $T 3$ indicated the volume of the concentrated transgenic or non-transgenic cotton root exudates added into the pot soil. Values are means $\pm S E$. Means with the same letters were not significantly different in LSD tests ( $p<0.05)$.

\section{Effect of root exudates of transgenic cotton seedlings on soil phosphatase activity}

The soil phosphatase activity in all treatments of root exudates of transgenic or conventional cotton seedlings was higher than control (Fig. 4). But the increment of the soil phosphatase activity depended on the concentrations. The increase degree of the phosphatase activity was from $29.8 \%$ to $63.1 \%$ regarding to control. However, the activity was gradually declined with increasing concentration. Still, no significant variation between transgenic and non-transgenic cotton was obtained.

\section{Effect of root exudates of transgenic cotton seedlings on soil bacterial and fungal community and diversity}

The total 16sPCR-DGGE lane bands of bacterial community and diversity in soil treated with root exudates of transgenic or non-transgenic cotton seedlings were almost kept unvaried. The shannon index and even index were changed little. However, the stability index decreased markedly with increasing concentration, particularly in the highest concentration $(4 \mathrm{ml} / 350 \mathrm{~g}$ soil). This indicated there is a little effect of root exudates of transgenic cotton on soil bacterial community while the bigger effect on soil 
bacterial community was obtained from the farther phylogenetic distance with control (Fig. 5). However, totally, the construction and composition of the soil bacterial community and diversity were not altered compared to control from the bacterial population stability. No obvious changes between transgenic and non-transgenic cotton were observed. This demonstrated that the key and dominant bacterial populations and community in the soil were not affected by the root exudates of transgenic cotton seedlings.

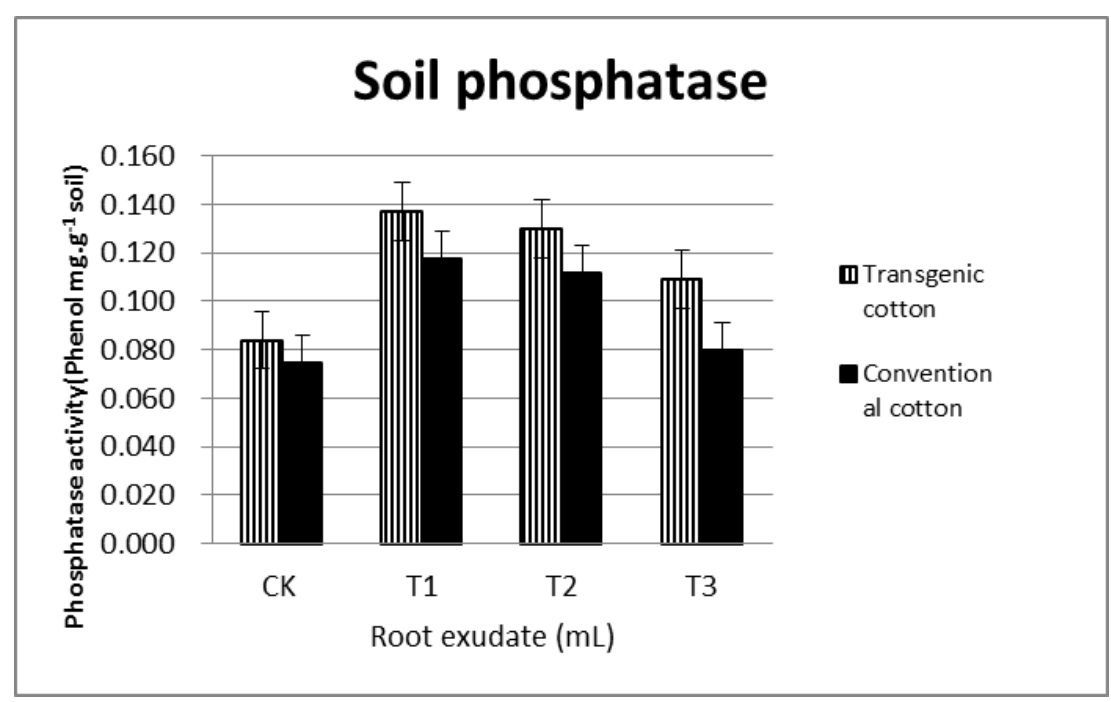

Figure 4. Effect of root exudates from transgenic and nont-transgenic cotton seedlings (Xinluhan-33, containing Bt and CpTI genes) on the soil phosphatase activity. The letters

$C K, T 1, T 2$, and T3 indicated the volume of the concentrated transgenic or non-transgenic cotton root exudates added into the pot soil. Values are means $\pm S E$. Means with the same letters were not significantly different in LSD tests ( $p<0.05$ ).

However, the effect pattern of root exudates of transgenic cotton on soil fungal community and diversity was differed from bacteria. From total lane bands of $18 \mathrm{~s}$ PCR-DGGE profile, the fungal community was significantly decreased ranging from 37 bands to 18 (Fig. 6, fungi). Fig. 6 showed the fungal community number and composition were changed. Some dominant community (bright lane bands) disappeared and other newly dominant community appeared. This clearly indicated root exudates of transgenic cotton could inhibit some fungus and stimulate some other fungus population. This was also evaluated from the evolution distance of phylogenetic tree of soil fungi based on $18 \mathrm{~s}$ PCR-DGGE (Fig .6). Further analysis from diversity index, Shannon index for fungi was decreased depending on the concentration, while even index was little varied, showing evenly decrease of fungal species number by root exudates. However, the fungal stability index was increased with the increasing concentration of root exudates of transgenic cotton, indicating the fungal population and community in the soil was not affected by the much higher concentration of root exudates of transgenic cotton. 


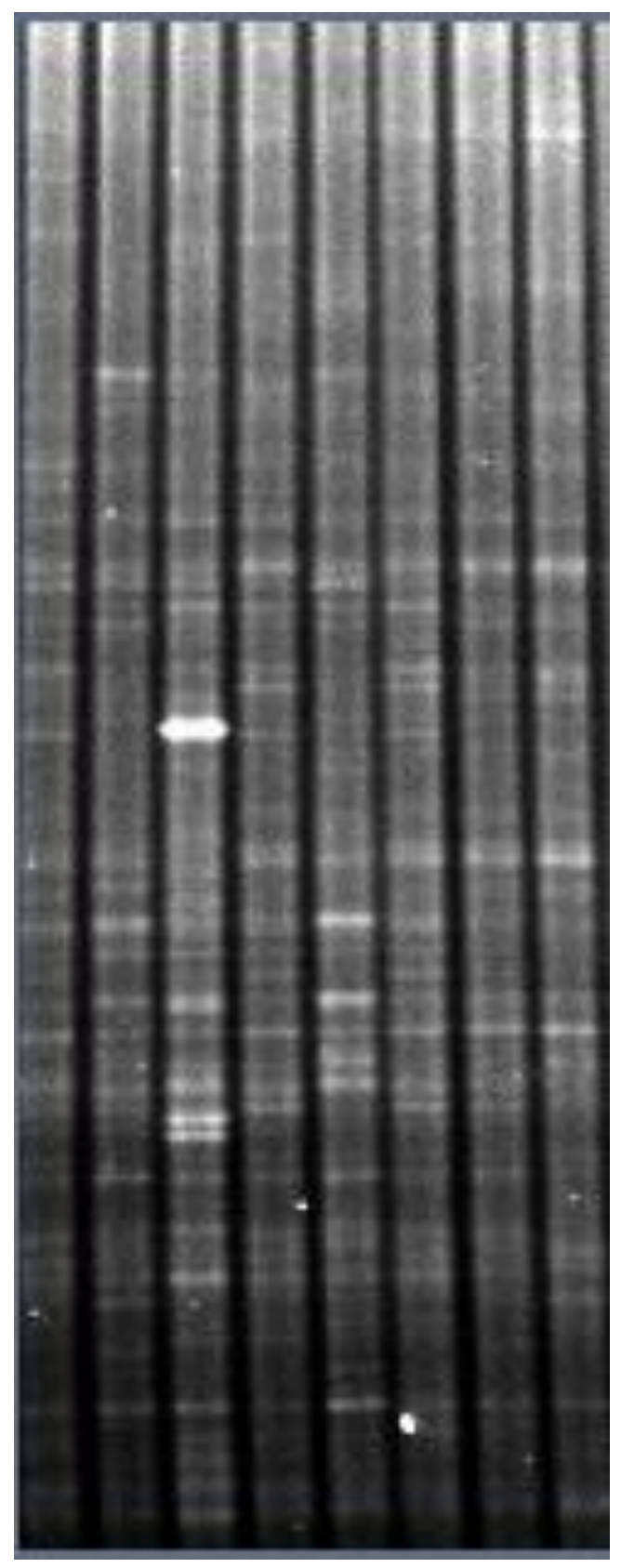

Figure 5. Effect of root exudates from transgenic and nont-transgenic cotton seedlings (Xinluhan-33, containing Bt and CpTI genes) on the soil bactrial community and diversity based on 16s PCR-DGGE for bacteria. The letters $C K, T 1, T 2$, and T3 indicated the volume of the concentrated transgenic and non-transgenic cotton root exudates added into the pot soil. From left to right, lane 1, 2,3,4,5,6,7,8 responded to treatments of Oml (control:no root exudates of transgenic cotton added), Oml (control:no root exudates of non-transgenic cotton added), $1 \mathrm{ml}$ (root exudates of transgenic cotton added), $1 \mathrm{ml}$ (root exudates of non-transgenic cotton added), $2 \mathrm{ml}$ (root exudates of transgenic cotton added), $2 \mathrm{ml}$ (root exudates of non-transgenic cotton added), $4 \mathrm{ml}$ (root exudates of transgenic cotton added), $4 \mathrm{ml}$ (root exudates of non-transgenic cotton added). 


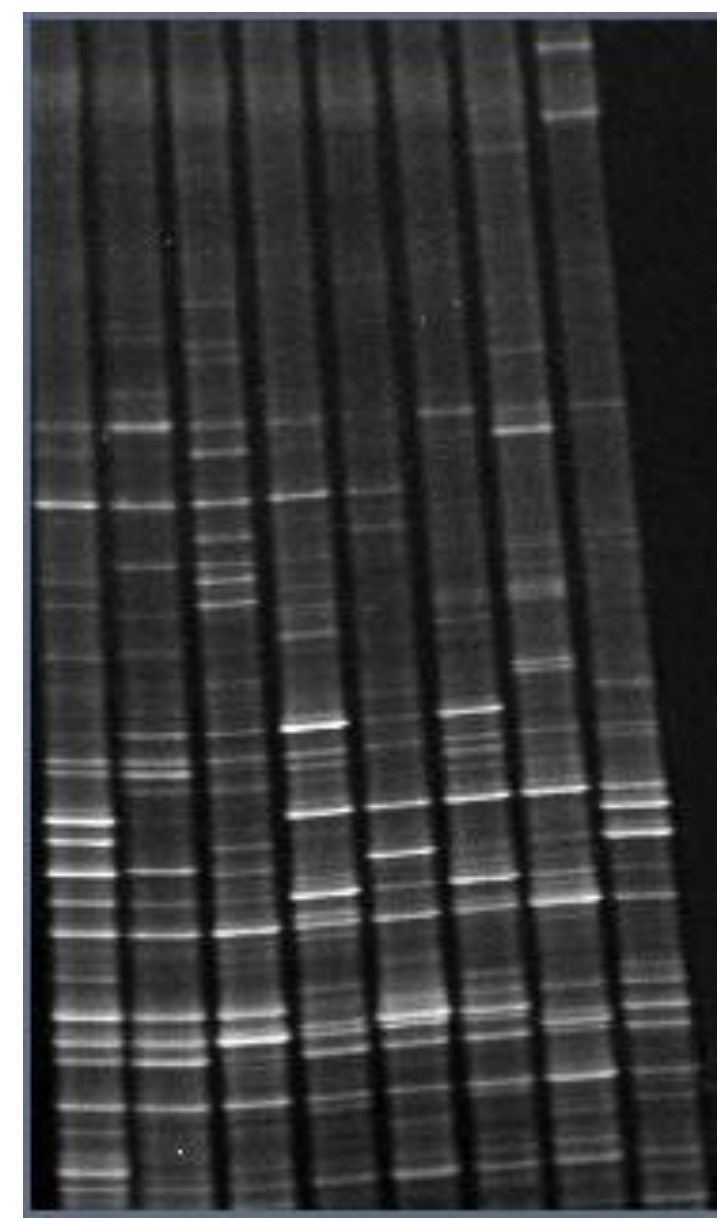

Figure 6. Effect of root exudates from transgenic and nont-transgenic cotton seedlings (Xinluhan-33, containing Bt and CpTI genes) on the soil fungal community and diversity based on 18s PCR-DGGE for fungi. The letters CK, T1, T2, and T3 indicated the volume of the concentrated transgenic and non-transgenic cotton root exudates added into the pot soil. From left to right, lane 1, 2,3,4,5,6,7,8 responded to treatments of Oml (control:no root exudates of transgenic cotton added), Oml (control:no root exudates of non-transgenic cotton added), $1 \mathrm{ml}$ (root exudates of transgenic cotton added), $1 \mathrm{ml}$ (root exudates of non-transgenic cotton added), $2 \mathrm{ml}$ (root exudates of transgenic cotton added), $2 \mathrm{ml}$ (root exudates of non-transgenic cotton added), $4 \mathrm{ml}$ (root exudates of transgenic cotton added), $4 \mathrm{ml}$ (root exudates of non-transgenic cotton added).

\section{Discussion}

Environmental problems related to plant genetic engineering may prohibit advancement of this technology and prevent realization of its full potential. One such common concern is the demonstrated escape of foreign genes through pollen dispersal from transgenic crop plants to their weedy relatives, creating super weeds or causing gene pollution among other crops or toxicity of transgenic pollen to non-target insects (Daniell, 1999). Another common issue is the effect of transgenic crops on their parental lines and other plants because plants interact with each other through root exudates in soil. Besides ecological effects on organisms in the aboveground compartment, effects on the below-ground 
compartment, in particular on soil and rhizosphere, have gained increasing attention. Soil has been recognized as a valuable resource for agriculture and therefore it has to be managed in a sustainable manner in order to maintain its quality (Widmer, 2007). The effect of transgenic Bt- and CpTI- cotton root exudates on the soil enzymes activities and soil microbial community and diversity was investigated in the current study.

Soil microbes and enzymes activities play a key role in the material decomposition, nutrients elements transformation, release and cycling, organic matter formation, soil fertility, promoting/suppressing plant growth, and various soil biological-physical-chemical processes (Zhang et al., 2014; Widmer, 2007; Critter et al., 2004; Hu et al., 2011). Soil enzymes can accelerate the above process, where the soil urease (urea amidohydrolase EC 3.5.1.5: catalyzing the hydrolysis of urea to $\mathrm{CO}_{2}$ and $\mathrm{NH}_{3}$ ) is very widely distributed in nature, hence, the efficient use of urea fertilizer in soil and the changes in urease activity can be used as an indirect indicator of the variation in the pool of potentially available $\mathrm{N}$ in a soil (Kulandaivelu et al., 2013; Rao and Ghai, 1985; Tabatabai, 1994; Bremner and Mulvaney, 1978). Activities of soil urease, acid phosphomonoesterase, invertase, and cellulase were stimulated by the addition of $\mathrm{Bt}$ cotton tissues (Sun et al., 2007). Catalase $\left(\mathrm{H}_{2} \mathrm{O}_{2}\right.$ oxidoreductase, E.C. 1, 11, 1.6) is widely associated with the tissues of animals, higher plants, and aerobic micro-organisms. Activities of catalase and various other enzymes in soils have been correlated with such soil variables as particle size, carbon content, nitrogen content, numbers of micro-organisms, and fertility.

Catalase activity of a cultivated soil was correlated with bacterial and fungal counts, cation exchange capacity, dehydrogenase activity, and cotton yield (Rodriguez-Kababa and Truelove, 1982). Soil catalase activity is considered as a sensitive indicator of aerobic microorganisms' activity and is related to both the number of the aerobic microorganism and soil fertility (Shiyin et al., 2004). Our results of several soil enzymes activities were also in agreement with this increase trend in the experimental concentrations much higher than possible actual concentrations of root exudates or residues of transgenic Bt and CpTI cotton, as the concentrations were condensed 1000-time in this study. However, the CAT activity was not always increased. Actually, the root exudates of transgenic cotton seedlings increased the soil CAT activity first and decreased the acitivity of soil CAT when peaking at $2 \mathrm{ml} / 350 \mathrm{~g}$ soil (Fig. 1). Our results showed the soil urease activity treated with root exudates of transgenic cotton seedlings was firstly higher than control but then slightly higher and finally less than the control at the highest concentration (Fig. 2).

Phosphatases have been extensively studied in soil, because they catalyse the hydrolysis of ester-phosphate bonds, leading to the release of phosphate $(\mathrm{P})$, which can be taken up by plants or microorganisms. It has been shown that the activities of phosphatases (like those of many hydrolases) depend on several factors such as soil properties, soil organism interactions, plant cover, leachate inputs and the presence of inhibitors and activators (Speir and Ross, 1978; Nannipieri et al., 2010). Acid phosphatase (EC 3.1.3.2) and alkaline phosphatase (EC 3.1.3.1) are phosphomonoesterases which are believed to play a significant role in soil $\mathrm{P}$ cycling, where these enzyme activities have been suggested as potential components of groups of indices to assess soil quality (Staddon et al., 1998). In the current study, the soil phosphatase activity in all treatments of root exudates of transgenic cotton seedlings was higher than control (Fig. 4). The increase degree of the phosphatase activity was from $29.8 \%$ to $63.1 \%$ regarding to control. However, the activity was gradually declined with increasing concentration. This was conformed by Shen et al. (2006) there were few 
significant differences in enzyme activities between Bt and non-Bt cottons at any of the growth stages and after harvest (Shen et al., 2006)

The soil invertase drives $\mathrm{C}$ cycling by catalyzing the hydrolysis of sucrose - thus, testing the activity of soil invertase may be useful for evaluating soil capability of decomposing complex organic compounds into subunits that can be assimilated by microorganisms or plants, in other words, such enzymatic indices would integrate other chemical, physical, and biological characteristics and could monitor the effects of agricultural management on soil's long-term productivity ( $\mathrm{Hu}$ et al., 2011; Mikhailouskaya and Bogdevitch, 2009). In the present investigation, root exudates of transgenic cotton seedlings could significantly affect the invertase activity of soil. Except the soil invertase activity treated with $1 \mathrm{ml} / 350 \mathrm{~g}$ soil was abruptly ascended, the activity in the other treatments was all sharply descended (Fig. 3). The invertase activity in the treatment of $1 \mathrm{ml} / 350 \mathrm{~g}$ soil was increased by $54.2 \%$, however, the activity in the treatments of 2 and $4 \mathrm{ml} / 350 \mathrm{~g}$ soil was decreased by from $25 \%$ to $29.2 \%$ relative to control. However, there was no significant difference among them. There were few significant differences in enzyme activities between Bt and non-Bt cottons at any of the growth stages and after harvest; amendment with cotton biomass to soil enhanced soil enzyme activities, but there were no significant difference between $\mathrm{Bt}$ and non-Bt cotton; the richness of the microbial communities in rhizosphere soil did not differ between $\mathrm{Bt}$ and the non-Bt cotton; the functional diversity of microbial communities were not different in rhizosphere soils between Bt and non-Bt cotton indicating no adverse effects of Bt cotton on the soil ecosystem (Shen et al., 2006). This was comply with our results.

Although there is large-scale adoption of Bt cotton by the farmers as immediate financial gain, there is concern that Bt crops release Bt toxins into the soil environment decreasing soil chemical and biological activities (Singh et al., 2013).Significantly higher dehydrogenase enzyme activity and $\mathrm{KMnO}_{4}-\mathrm{N}$ content of soil were observed in Bt cotton with cover crop of peanut over pure Bt cotton followed by pure peanut at all the crop growth stages (Singh et al., 2013).

Higher microbial population in soil was maintained by pure peanut over intercropped Bt cotton. By growing cover crop of peanut between Bt cotton rows, bacteria, fungi, and actinomycetes population increased by $60 \%, 14 \%$, and $10 \%$, respectively, over Bt cotton alone. Bt cotton fertilized by combined application of urea and farm yard manure maintained higher microbial population over urea alone. Significant positive correlations were observed for microbial population of soil of Bt cotton, which indicates no harmful effects of Bt cotton on soil biological parameters and associated cover crop (Singh et al., 2013). This was also supported by our results. The total 16s PCR-DGGE lane bands of bacterial community and diversity in soil treated with root exudates of transgenic cotton seedlings were almost little different, indicating almost no variation of bacterial community and diversity. Further, the shannon index and even index were changed little (Fig. 5), while the bigger effect on soil bacterial community was obtained from the farther phylogenetic distance with control (Fig. 5). However, totally, the construction and composition of the soil bacterial community and diversity were not altered compared to control from the bacterial population stability. This demonstrated that the key and dominant bacterial populations and community in the soil were not affected by the root exudates of transgenic cotton seedlings.

However, the effect pattern of root exudates of transgenic cotton on soil fungal community and diversity was differed from bacteria. From total lane bands of $18 \mathrm{~s}$ PCR-DGGE profile, the fungal community was significantly decreased ranging from 37 
bands to 18 (Fig. 6, fungi), where the fungal community number and composition were altered. Some dominant community (bright lane bands) disappeared and other newly dominant community appeared. This clearly suggested root exudates of transgenic cotton could inhibit some fungus and stimulate some other fungus population. This was also further evaluated from the evolution distance of phylogenetic tree of soil fungi based on 18s PCR-DGGE (Fig .6, fungi). Fungal diversity index, Shannon index for fungi in soil was decreased depending on the concentration of transgenic cotton, while even index was little varied, showing evenly decrease of fungal species number by root exudates (fungi). However, the fungal stability index was increased with the increasing concentration of root exudates of transgenic cotton, indicating the fungal population and community in the soil was not affected by the much higher concentration of root exudates of transgenic cotton (fungi). All these demonstrated that there was no significant adverse effect of transgenic Bt and CpTI-cotton on soil biology and microbes.

However, the concentration of Bt and CpTI cotton plant in the field soil was not reached so much high, maybe 1/10-1/100 as much as this study. Hence, the change of both soil enzymes activity and soil microbial community and composition in the current work will not be likely to happen. Of course, the investigation for a long term, 3-5 year, would need to further verify.

\section{Conclusions}

There was little but not significant adverse impact of transgenic Bt+CpTI cotton root exudates on soil microorgnisms and soil enzymes activity based conventional and molecular investigation, indicating posing little risks of $\mathrm{Bt}$ and CpTI-cotton to soil ecosystem. Though some changes of soil fungal community, biodiversity and composition were found, the so high concentrations of root exudates of transgenic Bt+CpTI cotton (condensed 1000 times) would not be possibly occurred in the actual field soil.

\section{REFERENCES}

[1] Baute, T.S., Sears, M.K., Schaafsma, A.W. (2002):Use of trangenic Bacillus thuringiensis Berliner corn hybrids to determine the direct economic impact of the European corn borer (Lepidoptera: Crambidae) on field corn in eastern Canada. - J Econ Entomol. 95(1): 57-64.

[2] Modirroosta, B. H., Tohidfar, M., Saba, J., Moradi F. (2014): The substantive equivalence of transgenic (Bt and Chi ) and non-transgenic cotton based on metabolite profiles. Funct. Integr. Genomics 14(1):237-244. DOI 10.1007/s10142-013-0355-y

[3] Bourguet, D., Chaufaux, J., Micoud, A., Delos, M., Naibo, B. (2002): Ostrinia nubilalis parasitism and the field abundance of non-target insects in transgenic Bacillus thuringiensis corn (Zea mays) - Environ Biosafety Res. 1(1):49-60.

[4] Bremner, J.M., Mulvaney, R.L. (1978): Urease activity in soils. - In: Burns, R.G. (ed) Soil enzymes. Academic Press, New York, pp 149-196.

[5] Rashid, B., Khan, G. A., Husnain, T., Riazuddin, S. (2009): Field evaluation and fiber analysis of transgenic cotton. - J. Crop Sci. Biotech. 12 (3):135 - 141.

[6] Chen, L., Cui, J., Ma, W., Niu, C., Lei, C. (2011): Pollen from Cry1Ac/CpTI-transgenic cotton does not affect the pollinating beetle Haptoncus luteolus. - J Pest Sci 84: 9-14.

[7] Critter, S. A. M., Freitas, S. S., Airoldi, C. (2004): Microcalorimetric measurements of the metabolic activity by bacteria and fungi in some Brazilian soils amended with different 
organic matter. -Thermochim Acta 417(2):275-281.

[8] Daniell, H. (1999): Environmentally friendly approaches to genetic engineering - Vitro Cell. Dev. Biol. - Plant 35:361-368.

[9] Saxena, D., Stewart, C. N., Altosaar, I., Shu, Q., Stotzky, G. (2004): Larvicidal Cry proteins from Bacillus thuringiensis are released in root exudates of transgenic $B$. thuringiensis corn, potato, and rice but not of $B$. thuringiensis canola, cotton, and tobacco. - Plant Physiology and Biochemistry 42(5):383-387.

[10] Devare, M., Londono-R, L.M., Thies, J.E. (2007): Neither transgenic Bt maize (MON863) nor tefluthrin insecticide adversely affect soil microbial activity or biomass: A 3-year field analysis. - Soil Biology \& Biochemistry 39: 2038-2047.

[11] Environmental Protection Agency (1998): The Environmental Protection Agency's white paper on Bt plant-pesticide resistance management. Publication 739-S-98-001. US Environmental Protection Agency, Washington, DC.

[12] Widmer, F. (2007): Assessing effects of transgenic crops on soil microbial communities. Adv Biochem Engin/Biotechnol 107: 207-234.

[13] Frankenberger Jr., W.T., Johanson, J.B. (1983): Method of measuring invertase activity in soils - Plant and Soil 74:301-311.

[14] Gomez, E., Ferreras, L., Toresani, S. (2006): Soil bacterial functional diversity as influenced by organic amendment application. - Bioresource Technology 97: 1484-1489.

[15] Han, C., Zhong, W., Shen, W., Cai, Z., Liu, B. (2013): Transgenic Bt rice has adverse impacts on $\mathrm{CH} 4$ flux and rhizospheric methanogenic archaeal and methanotrophic bacterial communities. - Plant Soil 369:297-316.

[16] Hu, J., Lin, X., Wang, J., Dai, J., Chen, R., Zhang, J., Wong, M. H. (2011): Microbial functional diversity, metabolic quotient, and invertase activity of a sandy loam soil as affected by long-term application of organic amendment and mineral fertilizer. - J Soils Sediments 11:271-280.

[17] Icoz, I., Stotzky, G. (2008): Fate and effects of insect-resistant Bt crops in soil ecosystems. - Soil Biology and Biochemistry 40:559-586.

[18] Serrasolsas, I., Khanna, P. K. (1995): Changes in heated and autoclaved forest soils of S.E. Australia. II. Phosphorus and phosphatase activity - Biogeochemistry 29: 25-41.

[19] James, C. (2010): Global status of commercialized biotech/GM crops, ISAAA Brief 42.

[20] Johnson, J. I., Temple, K. L. (1964): Some variables affecting the measurement of catalase activity in soil. - Soil Science Society of America Processes 28: 207-216.

[21] Kandeler, E., Gerber, H. (1988): Short-term assay of soil urease activity using colorimetric determination of ammonium. - Biol. Fertil. Soils 6:68-72.

[22] Knox, O.G.G., Nehl, D.B., Mor, T., Roberts, G.N., Gupta, V.V.S.R. (2008): Genetically modified cotton has no effect on arbuscular mycorrhizal colonisation of roots. - Field Crops Research 10957-60.

[23] Kulandaivelu Velmourougane, Venugopalan, M. V., Bhattacharyya, T., Dipak Sarkar, Pal, D. K., Apeksha Sahu, Chandran, P., Ray, S. K., Champa Mandal, Nair, K. M., Jagdish Prasad, Singh, R. S., Pramod Tiwary (2013): Urease Activity in Various Agro-ecological Sub-regions of Black Soil Regions of India - Proc. Natl. Acad. Sci., India, Sect. B Biol. Sci. 83(4):513-524.

[24] Shiyin, L., Lixiao, N., Panying, P., Cheng, S., Liansheng, W. (2004): Effects of Pesticides and Their Hydrolysates on Catalase Activity in Soil - Bull. Environ. Contam. Toxicol. 72 (3): 600-606.

[25] Li, X., Liu, B., Cui, J., Liu, D., Ding, S., Gilna, B., Luo, J., Fang, Z., Cao, W., Han, Z. (2011): No evidence of persistent effects of continuously planted transgenic insect-resistant cotton on soil microorganisms. - Plant Soil 339 (1): 247-257.

[26] Liu, B., Xu, C., Yan, F., Gong, R. (2005a): The impacts of the pollen of insect-resistant transgenic cotton on honeybees. - Biodiversity and Conservation 14: 3487-3496.

[27] Liu, B., Zeng, Q., Yan, F., Xu, H., Xu, C. (2005b): Effects of transgenic plants on soil microorganisms. - Plant and Soil 271: 1-13. 
[28] Luo, J., Ran, W., Hu, J., Yang, X., Xu, Y., Shen, Q. (2009): Application of Bio-Organic Fertilizer Significantly Affected Fungal Diversity of Soils. - Soil Science Society of American Journal 74(6): 2039-2048.

[29] May, L.A., Smiley, B., Schmidt, M.G. (2001): Comparative denaturing gradient gel electrophoresis analysis of fungal communities associated with whole plant corn silage. Canadian Journal of Microbiology 47:829-841.

[30] Men, X., Ge, F., Edwards, C. A., Yardim, E. N. (2004): Influence of pesticide applications on pest and predatory arthropods associated with transgenic Bt cotton and nontransgenic cotton plants. - Phytoparasitica 32(3): 246-254.

[31] Nannipieri, P., Giagnoni, L., Landi, L., Renella, G. (2010): Role of Phosphatase Enzymes in Soil (Chapter 9). - In: Bgunemann, E.K. et al. (eds.) Phosphorus in Action - Soil Biology, Volume 26. Springer-Verlag Berlin Heidelberg, pp. 215-243.

[32] Nannipieri, P., Ascher, J., Ceccherini, M. T., Landi, L., Pietramellara, G., Renella, G. (2003): Microbial diversity and soil functions. - European Journal of Soil Science 54:655-670.

[33] Peferoen, M. (1997): Progress and prospects for field use of Bt genes in crops. - Trends Biotech. 15:173-177.

[34] Radojkovic, D., Kusic, J. (2000): Silver staining of denaturing gradient gel electrophoresis gels - Clinical Chemistry 46(6):341-345.

[35] Rahman, M., Zaman, M., Shaheen, T., Irem, S., Zafar, Y. (2015): Safe use of Cry genes in genetically modified crops. - Environmental Chemistry Letter 13:239-249.

[36] Rao, D.L.N., Ghai, S.K. (1985): Urease and dehydrogenase activity of alkali and reclaimed soils. - Aust J Soil Res 23: 661-665.

[37] Riglietti, A., Ruggiero, P., Crecchio, C. (2008): Investigating the influence of transgenic tobacco plants codifying a protease inhibitor on soil microbial community. - Soil Biology and Biochemistry 40: 2928-2936.

[38] Rodriguez-Kababa, R., Truelove, B. (1982): Effects of crop rotation and fertilization on catalase activity in a soil of the southeastern United States - Plant and Soil 69: 97-104.

[39] Rui, Y-K. , Yi, G-X., Zhao, J., Wang, B-M., Li, Z-H., Zhai, Z-X., He, Z-P., Li, Q. X. (2005): Changes of Bt toxin in the rhizosphere of transgenic Bt cotton and its influence on soil functional bacteria. - World Journal of Microbiology and Biotechnology 21: 1279-1284.

[40] Shen, R. F., Cai, H., Gong, W. H. (2006): Transgenic Bt cotton has no apparent effect on enzymatic activities or functional diversity of microbial communities in rhizosphere soil. - Plant Soil 285:149-159.

[41] Singh, R. J., Ahlawat, I. P. S., Singh, S. (2013): Effects of transgenic Bt cotton on soil fertility and biology under field conditions in subtropical inceptisol. - Environ Monit Assess 185: 485-495.

[42] Speir, T.W., Ross, D.J. (1978): Soil phosphatase and sulphatase. - In: Burns, R.G. (ed) Soil enzymes. Academic, London, pp 197-250.

[43] Staddon, W. J., Duchesne, L.C., Trevors, J.T. (1998): Acid phosphatase, alkaline phosphatase and arylsulfatase activities in soils from a jack pine (Pinus banksiana Lamb.) ecosystem after clear-cutting, prescribed burning, and scarification. - Biol Fertil Soils 27:1-4.

[44] Stotzky, G. (2004): Persistence and biological activity in soil of the insecticidal proteins from Bacillus thuringiensis, especially from transgenic plants. - Plant and Soil 266:77-89.

[45] Sun, C. X., Chen, L. J., Wu, Z. J., Zhou, L. K., Shimizu, H. (2007): Soil persistence of Bacillus thuringiensis (Bt) toxin from transgenic Bt cotton tissues and its effect on soil enzyme activities - Biol Fertil Soils 43:617-620.

[46] Tabatabai, M.A. (1994): Soil enzymes. - In: Weaver, R.W., Angle, J.S., Bottomley, P.S. (eds) Methods of soil analysis. Part 2. Microbiological and biological properties, 2nd edn. -Soil Science Society of America, Madison, pp 775-833. 
[47] Talas-Ogras, T. (2011): Risk assessment strategies for transgenic plants. - Acta Physiol Plant 33: 647-657.

[48] Velkov, V. V., Medvinsky, A. B., Sokolov, M. S., Marchenko, A. I. (2005): Will transgenic plants adversely affect the environment? - J. Biosci. 30(4): 515-548.

[49] Velasco, A. G. V., Kowalchuk, G. A., Gutierrez Manero, F. J., Ramos, B., Yergeau, E., Lucas Garcia, J. A. (2013): Increased microbial activity and nitrogen mineralization coupled to changes in microbial community structure in the rhizosphere of Bt corn. Applied Soil Ecology 68:46-56.

[50] White, T.J., Bruns,T., Lee, S., Taylor, J.W. (1990): Amplification and direct sequencing of fungal ribosomal RNA genes for phylogenetics. - In: Innis, M. A. et al. (eds.) PCR protocols: A guide to methods and applications. Academic Press, New York., pp 315-322.

[51] Yuan, Y., Xiao, N., Krogh, P. H., Chen, F., Ge, F. (2013): Laboratory assessment of the impacts of transgenic Bt rice on the ecological fitness of the soil non-target arthropod, Folsomia candida (Collembola: Isotomidae). - Transgenic Res 22:791-803.

[52] Zabalzaa, A., Gastona, S., Sandaliob, L.M., del Riob, L.A., Royuel, M. (2007): Oxidative stress is not related to the mode of action of herbicides that inhibit acetolactate synthase. Environ Exp Bot 59: 150-159.

[53] Zaman, M., Mirza, M.S., Irem, S., Zafar, Y., Rahman, M. (2015): A temporal expression of Cry1Ac protein in cotton plant and its impact on soil health. - Int J Agric Biol 17: 280-288.

[54] Zhang, T-B., Kang, Y., Liu, S-H., Liu, S-P. (2014): Alkaline phosphatase activity and its relationship to soil properties in a saline-sodic soil reclaimed by cropping wolfberry (Lycium barbarum L.) with drip irrigation - Paddy Water Environ 12: 309-317.

[55] Zhang, Y., Liu, Y., Ren, Y., Liu, Y., Liang, G., Song, F., Bai, S., Wang, J., Wang, G. (2013): Overexpression of a novel Cry1Ie gene confers resistance to Cry1 Ac-resistant cotton bollworm in transgenic lines of maize. - Plant Cell Tiss Organ Cult 115:151-158.

[56] Zwahlen, C., Hilbeck, A., Nentwig, W. (2007): Field decomposition of transgenic Bt maize residue and the impact on non-target soil invertebrates. - Plant Soil 300: 245-257. 